\title{
PERFORMA RUMPUT LAUT, Gracilaria gigas, PADA SISTIM BUDIDAYA LAUT DAN TAMBAK
}

\section{PERFORMANCE OF SEAWEED, Gracilaria gigas, AT SEA CULTURE AND PONDS SYSTEMS}

\author{
Farah Diana ${ }^{1}$ \\ ${ }^{1}$ Program Studi Perikanan, Fakultas Perikanan dan Ilmu Kelautan, Universitas Teuku Umar, Aceh Barat \\ Korespondensi : farahdiana@utu.ac.id
}

\begin{abstract}
Gracilaria gigas is one of seaweed species the from red algae type (Rhodophyceae) producsy agarofit, G. gigas have the high fiber and good for health. The research aims to analyze the performance of production, yield and quality of $G$. gigas seaweed cultivated in the sea and in the ponds. The cultivation of G. gigas in ponds was held in Sekotong, west Lombok by broadcast method in $1500 \mathrm{~m}^{2}$ planting area. While cultivation in the sea was held in Gerupuk Bay, Central Lombok by Longline method the $1250 \mathrm{~m}^{2}$. Parameters measured include the performance of seaweed, and water quality. While water quality parameters measured are temperature, salinity, $\mathrm{pH}, \mathrm{NO} 3-\mathrm{N}, \mathrm{NO} 2-\mathrm{N}, \mathrm{NH} 3-\mathrm{N}, \mathrm{PO} 4-\mathrm{P}$ and brightness were taken on days 0,10 , 20 and 30. Based on the research results obtained performance parameters seaweed cultivation consisting of productivity of cultivation, the total number thalus ( JT ), the number of thalus secondary ( JTS ), the number of thalus tertiary ( AAC) and the index of branching ( IP ) from seaweed cultivated on two habitats different, namely marine and pond. The average productivity of Gracilaria . gigas were in cultivation in the sea that is $12.72 \%$, whereas in ponds with an average of $4.00 \%$. Total thalus on Gracilaria gigas cultured in ponds is high ( 86.56 ) than in the sea ( 80.40 ). Branching index is closely related to the availability of nutrients and nutrient in the formation of new cells , in which the $\mathrm{N}$ content in ponds is higher than in the sea. In addition, the number of tertiary thalus.
\end{abstract}

Keywords : Gracilaria gigas, performance, seaweed culture

\section{Pendahuluan}

Rumput laut merupakan tumbuhan tingkat rendah berupa thallus (batang) yang bercabang-cabang, dan hidup di laut dan tambak dengan kedalaman yang masih dapat dicapai oleh cahaya matahari. Salah satunya adalah G. gigas yang merupakan salah satu spesies rumput laut yang umum dibudidayakan di tambak sebagai penghasil agar (agarofit). Di indonesia G. gigas umumnya dibudidayakan di tambak, karena kandungan agarnya, sehingga spesies ini digolongkan pada penghasil agarofit. Pada awalnya perkembangan industri agar, G. gigas hanya dikumpulkan dari alam dengan tujuan untuk menutupi keterbatasan suplai dari jenis rumput yang dianggap sebagai penghasil utama agar yaitu, Gelidium sp. Namun karena kebutuhan akan spesies ini semakin meningkat, maka di Chili dikembangkan teknik budidayanya di tambak maupun di perairan laut khususnya pada teluk tertutup. Teknik budidaya tersebut yang kemudian menyebar ke berbagai negara seperti Cina, Korea, Indonesia, Namibia, 
Filipina, dan Vietnam yang diaplikasikan untuk spesies asli G. gigas dari masingmasing negara tersebut (McHugh 2003).

Teknologi budidaya rumput laut yang berkembang di masyarakat saat ini umumnya masih bersifat tradisional. Bibit yang digunakan masih berasal dari indukan yang sama dan tidak dilakukan seleksi bibit, pola tanam dan siklus produksi kurang menjadi perhatian, sehingga kualitas rumput laut yang dihasilkan semakin menurun. Metode budidaya yang umumnya diaplikasikan oleh pembudidaya antara lain metode long-line, lepas dasar, rakit serta brodcast pada budidaya di tambak. Saat ini permasalahan yang umumnya dihadapi dalam budidaya rumput laut jenis G. gigas antara lain sulitnya memperoleh bibit yang berkualitas, kondisi cuaca yang berubahubah dan tidak dapat diprediksi, kurangnya nutrien diperairan, serta serangan hama, penyakit ice-ice dan ikan-ikan pemakan rumput laut (Chen Jia Xin 1989). Rumput laut jenis G. gigas memiliki habitat asli di laut. Di alam G. gigas hidup dengan cara menempel pada substrat dasar perairan atau benda lainnya pada daerah pasang surut. Bahkan pada musim-musim tertentu rumput laut jenis ini banyak terdampar di pantai karena hempasan gelombang dalam jumlah yang sangat besar dan berakibat tidak cukup untuk produksi. Gracilaria tersebar luas disepanjang pantai daerah tropis (Anggadiredja 1992). Gracilaria umumnya tumbuh di perairan yang mempunyai rataan terumbu karang melekat pada substrat karang mati atau kulit kerang, pecahan koral dan batu karang pada perairan dengan dasar berpasir dibawah area pasang surut (Terada \& Ohno 2000; Hirotoshi 1978).

Hingga saat ini hasil budidaya G. gigas di tambak belum dapat mencukupi pasar terutama industri agar-agar akan G. gigas kering sebagai bahan baku utama penghasil agar. Intensifikasi budidaya $G$. gigas hingga saat ini terus digalakkan guna mencukupi kebutuhan industri agar-agar. Salah satu upaya untuk meningkatkan produksi G. gigas adalah dengan cara budidaya di laut. Untuk memenuhi taraf hidup bagi masyarakat nelayan maupun pesisir, maka dilakukan budidaya di laut. Selain dapat memenuhi permintaan pasar juga akan berperan melestarikan lingkungan, terutama sumber daya rumput laut, sebagai salah satu komoditas internasional (Anonymous 2005), yang menghasilkan rumput laut berkualitas baik. Potensi rumput laut di Indonesia mempunyai prospek yang cukup cerah, karena diperkirakan terdapat 555 spesies rumput laut yang tersebar di perairan Indonesia dengan total luas lahan perairan yang dapat dimanfaatkan sebesar 1,2 hektar. Rumput laut merupakan bahan baku dari berbagai jenis produk olahan bernilai ekonomi tinggi, sebagai pewarna makanan dan tekstik, juga dapat digunakan sebagai produk pangan maupun non pangan, seperti agar-agar, keraginan dan alginat.

Indonesia memiliki perairan luas dan mendukung budidaya rumput laut. Beberapa kendala masih dihadapi dalam pengembangan industri rumput laut antara lain ketersediaan bibit bermutu, pengetahuan dan ketrampilan para pembudidaya dalam menghasilkan rumput laut berkualitas baik. Berdasarkan habitat aslinya yaitu di laut, perlu dilakukan penelitian untuk mengetahui produktifitas G. gigas yang dibudidayakan 
di tambak, dan perbedaannya dari segi kuantitas dan kualitas dibandingkan dengan hasil budidaya di laut.

\section{Metode Penelitian}

Bibit rumput laut yang digunakan dalam penelitian ini adalah jenis Gracilaria gigas dari di Sekotong, Kabupaten Lombok Barat. Budidaya dilakukan di laut dan di tambak. Budidaya rumput laut di laut menggunakan metode Long-line dengan unit budidaya $25 \times 50 \mathrm{~m}^{2}$, sedangkan budidaya di tambak dengan metode broadcast. Budidaya berlangsung selama satu siklus dengan masa pemeliharaan 30 hari sesuai kebiasaan masyarakat pembudidaya rumput laut di lokasi tersebut. Selama masa pemeliharaan dilakukan pengontrolan 10 hari sekali. Selama penelitian dilakukan pengujian terhadap sampel air laut dan tambak dari lokasi budidaya yang diambil pada hari ke-0, 10, 20 dan 30. Parameter uji yang diamati selama penelitian meliputi : kualitas rumput laut (rendemen agar, CAW, kadar air, serat kasar dan kadar abu), agar (viskositas, kekuatan gel, derajat putih, titik jendal, titik leleh dan kadar sulfat), produktifitas rumput laut Gracilaria gigas, indeks percabangan (branching index) rumput laut dan, kualitas perairan lokasi budidaya.

Seluruh data dianalisis menggunakan uji nilai tengah statistika deskriptif (t-test). Hubungan parameter kualitas air dan indeks percabangan dianalisis dengan menggunakan metode cluster analysis dan analisis komponen utama (principal component analysis).

\section{Hasil dan Pembahasan}

\subsection{Performa Rumput Laut}

Berdasarkan hasil penelitian maka didapatkan parameter performa budidaya rumput laut yang terdiri atas produktifitas budidaya, jumlah total thalus (JT), jumlah thalus sekunder (JTS), jumlah thalus tersier (JTT) dan indeks percabangan (IP) dari rumput laut yang dibudidayakan pada dua habitat yang berbeda, yaitu laut dan tambak.

Produktifitas Gracilaria gigas yang dibudidaya di laut tiga kali lipat lebih tinggi $(12,72 \%)$ dibandingkan dengan yang budidaya di tambak (Gambar 1). Menurut Kadi dan Atmadja (1988) budidaya Gracilaria gigas di laut terjadi pembesaran sel akibat adanya tekanan pasang surut dan arus, dan menurut Dawes (1981) di laut terjadi respon struktural pada algae terhadap cahaya yang mengakibatkan perbedaan morfologi, reproduksi, fisiologi dan sitoplasmik sehingga pertumbuhan memanjang dan sel membesar maka tekanan turgor didalam sel akan mudah masuk dan menyebabkan thallus sekunder yang dibudidayakan di laut juga lebih tinggi $(36,20)$. Sedangkan di tambak pertumbuhan lebih kearah reproduktif (membangun sel baru menjadi individu baru dengan memperbanyak sel generatif). Dawes et al (1981) menyatakan budidaya rumput laut Gracilaria gigas pada kondisi lingkungan yang berbeda akan menghasilkan produktifitas yang berbeda akan menghasilkan produksi yang berbeda. Walaupun $G$. gigas merupakan habitat asli di laut, namun di tambak juga dapat di produksi dengan metode dan budidaya yang berkembang saat ini. 


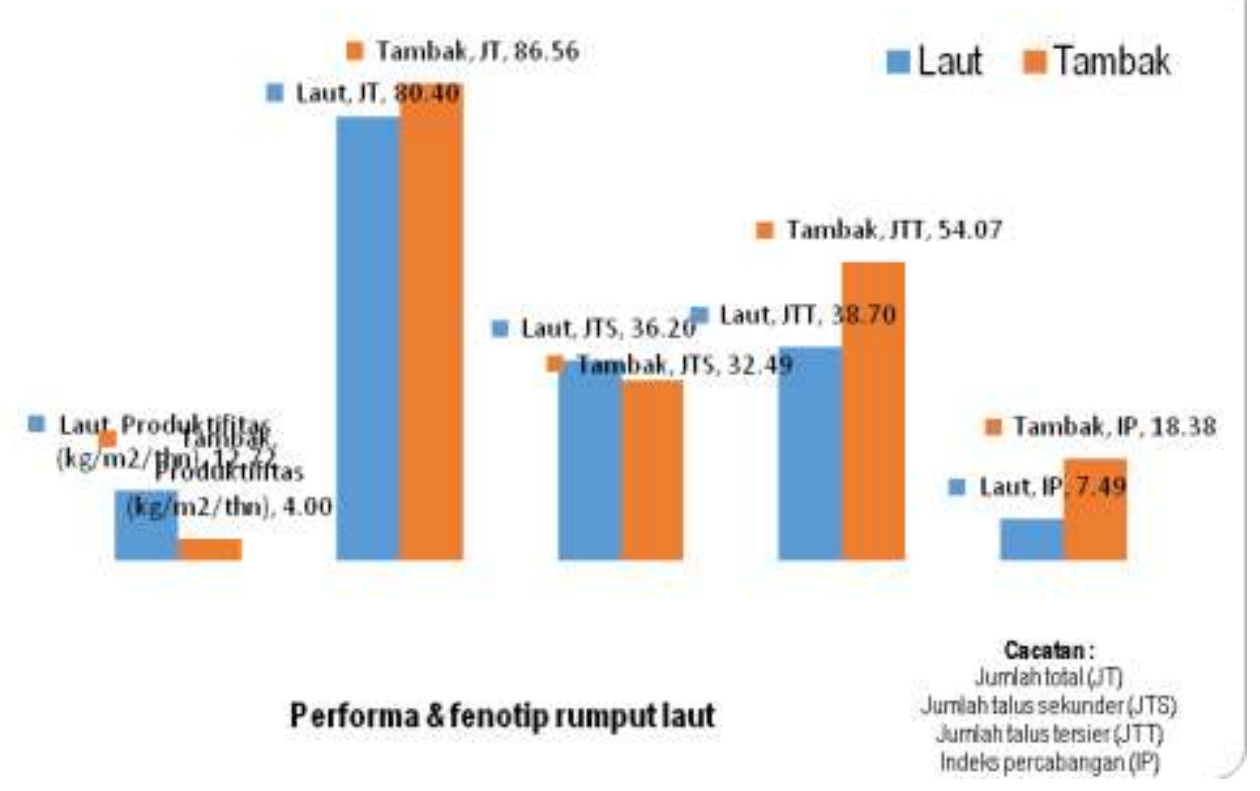

Gambar 1. Performa rumput laut Gracilaria gigas

Jumlah thalus pada Gracilaria gigas yang dibudidaya di tambak tinggi $(86,56)$ dibandingkan dengan di laut $(80,40)$, demikian jumlah thalus tersier $(54,07)$ dan indeks percabangan (18,38). Menurut Pickering et al (1995), indeks percabangan erat kaitannya dengan ketersediaan nutrient dan unsur hara dalam pembentukan sel baru, dimana kandungan $\mathrm{N}$ di tambak lebih tinggi dibandingkan dengan di laut. Selain itu, jumlah thalus tersier dua kali lipat lebih tinggi di tambak $(54,07)$ dibandingkan dengan di laut $(38,70)$, hal ini berhubungan erat dengan indeks percabangan.

Habitat asli dari rumput laut G. gigas di alam adalah di laut. Pada penelitian ini budidaya $G$. gigas ditanam pada dua habitat yang berbeda, yaitu ditambak dan di laut. Hasil penelitian menunjukkan bahwa budidaya rumput laut dengan metode long-line di laut menghasilkan pertambahan bobot basah yang lebih tinggi di bandingkan dengan metode tebar pada tambak. Pada metode long-line menunjukkan produktivitas rumput laut yang lebih tinggi dibandingkan di tambak. Pada budidaya rumput laut di perairan tambak yang memiliki kandungan nutrien relatif tinggi, kualitas air cukup berpengaruh pada kualitas agar yang dihasilkan oleh rumput laut. Hal ini disebabkan nutrien yang diserap oleh rumput laut memberikan peluang terjadinya proses pertumbuhan ke arah reproduktif, pada saat terbentuknya spora yang baru pada percabangan sekunder terjadinya perbanyakan sel sehingga terbentuk sel-sel baru serta terbentuknya talus tersier. Hal ini berpengaruh pada terbentuknya percabangan rumput laut laut yang lebih banyak. Menurut Dawes (1981), unsur hara dibutuhkan sebagai salah satu bahan dasar untuk menyusun energi guna memnuhi kebutuhan metabolisme. Tingginya nutrien di tambak disebabkan oleh adanya buangan feses ikan yang akan diserap oleh rumput laut untuk membentuk sebagai sumber nutrien dalam pembentukan sel baru. Banyaknya nutrien dan unsur hara akan meningkatkan kualitas agar, karena nutrien yang diserap 
oleh rumput laut akan membentuk selulosa, polisakarida dan galaktosa pada rumput laut. (Dawes 1981).

\subsection{Hubungan parameter lingkungan perairan di laut dengan performa dan kualitas rumput laut Gracilaria gigas}

Tingkat keeratan antara indeks percabangan dengan variabel kualitas air di laut digambarkan pada gambar 2. Variabel-variabel yang memiliki korelasi positif dengan indeks percabangan yaitu, kecerahan, $\mathrm{NO}_{3}, \mathrm{NH}_{3}-\mathrm{N}$, dan DO. Berdasarkan nilai koefisien korelasinya, ada dua variabel memiliki hubungan korelasi yang tinggi dengan indeks percabangan pada rumput laut yaitu kecerahan $(0,34)$ dan DO $(0,24)$.

Variabel-variabel yang berkorelasi negatif dengan indeks percabangan pada rumput laut yaitu $\mathrm{PO}_{4}-\mathrm{P}, \mathrm{pH}$, salinitas dan suhu (Gambar 2). Diantara variabel-variabel tersebut terdapat tiga variavel yang memiliki nilai korelasi yang tinggi yaitu salinitas $(0,87), \mathrm{PO}_{4}-\mathrm{P}(0,31)$ dan $\mathrm{pH}(0,14)$.

Dari hasil korelasi antara indek percabangan dan parameter kualitas air di laut menunjukkan kecerahan berhubungan positif dengan indek percabangan hali ini disebabkan karena, kemampuan adaptasi G. gigas di laut terhadap cahaya sangat baik. Cahaya yang masuk ke perairan baik dalam jumlah banyak atau sedikit dapat dimanfaatkan untuk pertumbuhannya. Kim \& Hum (dalam Hoyle 1975) menyatakan bahwa G. gigas, G. verrucosa dan G. foliifera memiliki toleransi yang tinggi terhadap cahaya yang berlebihan, keduanya dapat tumbuh pesat pada kedalaman $5 \mathrm{~cm}$.

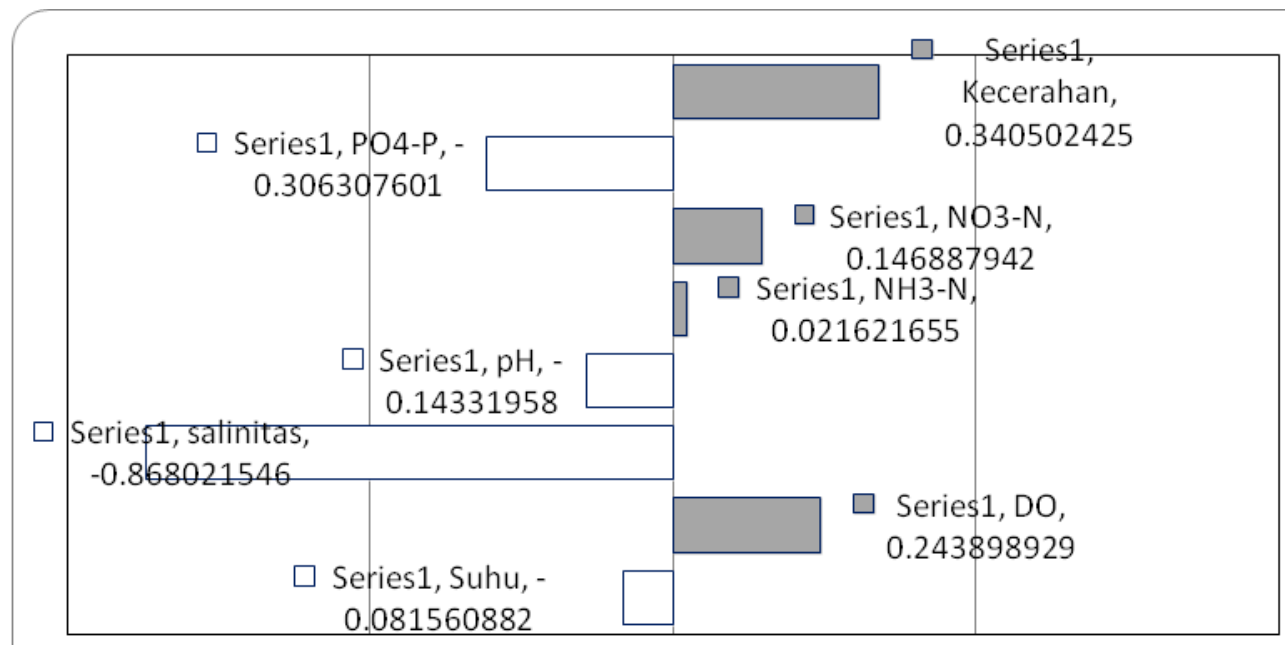

Koefisien korelasi

Gambar 2. Koefisien korelasi antara indek percabangan rumput laut Gracilaria gigas dengan parameter kualitas air

Semakin tinggi tingkat kecerahan semakin rendah tingkat percabangan dan pada rumput laut yang di budidaya di laut pertumbuhan G. gigas lebih memanjang. 
Sedangkan rendahnya fosfat di perairan disebabkan sumber fosfat yang lebih sedikit di perairan, karena fosfat dapat menjadi faktor pembatas baik secara temporel maupun spasial (Raikar et al. 2000). Cahaya matahari merupakan sumber energi dalam proses fotosintesis. Pada proses fotosintesis terjadi pembentukan bahan organik yang diperlukan bagi pertumbuhan dan perkembangan. Widyorini (2010) menyatakan bahwa cahaya menyediakan energi bagi terlaksananya fotosintesis, sehingga kemampuan penetrasi cahaya pada kedalaman tertentu sangat menentukan distribusi vertikal organisme perairan. Hal yang berhubungan erat dengan penetrasi cahaya adalah kecerahan perairan. Kecerahan perairan yang ideal lebih dari $1 \mathrm{~m}$. Air yang keruh (biasanya mengandung lumpur) dapat menghalangi tembusnya cahaya matahari di dalam air sehingga proses fotosintesis menjadi terganggu. Hal ini akan berdampak buruk terhadap pertumbuhan dan perkembangan rumput laut (Guanzon 2003).

Kisaran fosfat yang optimal untuk pertumbuhan rumput laut adalah 0,051-1,00 ppm (Indriani dan Sumiarsih 1997). Karena fosfor merupakan unsur hara yang penting yang dibutuhkan oleh rumput laut. Semakin rendah fosfat yang ada di perairan, maka semakin rendah percabangan yang terbentuk, hal ini disebabkan fosfat adalah faktor pendukung dalam pembentukan talus rumput laut. Pertumbuhan Gracilaria di laut sangat bagus, akan tetapi rendahnya fosfat akan menghambat pembentukan talus yang baru, akibat respon struktural yang mengakibatkan pembesaran sel. Fosfor merupakan salah satu pembentuk daun pada tanaman, akan tetapi pada rumput laut merupakan pembentukan talus, yang menghasilkan sel-sel yang baru.

Dari hasil korelasi nitrat berhubungan positif dengan indek percabangan, karena tingginya kadar nitrat pada perairan alami biasanya jarang melebihi $0,1 \mathrm{mg} / 1$, sedangkan kadar nitrat yang melebihi $0,2 \mathrm{mg} / \mathrm{l}$ dapat mengakibatkan eutrofikasi yang selanjutnya menstimulir pertumbuhan alga dan tumbuhan air secara pesat (Gerung \& Yuo 2009). Lebih lanjut lagi, Ahda et al. (2005), menyebutkan bahwa kadar nitrat terendah untuk pertumbuhan alga berkisar 0,3-0,9 mg/l. Amoniak di laut juga bekorelasi positif dengan percabangan, hal ini disebabkan kandungan amoniak di laut sangat rendah, karena amoniak berperan sebagai pembentuk protein dan urea pada rumput laut ( Chen Jia Xin 1989). Amoniak merupakan sumber nitrogen utama di perairan, akan tetapi amonium lebih disukai oleh tumbuhan sebagai sumber nitrogen. Hasil korelasi pH menunjukkan nilai yang negatif pada indeks percabangan. Semakin tingginya $\mathrm{pH}$, maka pertumbuhan rumput laut akan semakin rendah, karena $\mathrm{pH}$ berperan sebagai penunjang kelangsungan hidup pada G. gigas. Sedangkan korelasi dengan salinitas, semakin rendah salinitas, maka tingkat pertumbuhan semakin rendah. G. gigas merupakan rumput laut yang bersifat euryhalin, salinitas untuk pertumbuhan yang optimal untuk Gracialria berkisar 10-28 ppt (Anggadiredja 1998). Salinitas di perairan berperan sebagai proses fisologis, reproduksi, morfologi dan termasuk dalam laju fotosintesis.

Semakin tinggi oksigen terlarut di perairan, maka pertumbuhan akan rumput laut semakin bagus. Oksigen terlarut merupakan faktor pembatas pada pertumbuhan rumput laut, kurangnya oksigen akan menghambat petumbuhan rumput laut ( Ahda et al. 2005). Hasil korelasi suhu berhubungan negatif pada indeks percabangan. Di perairan suhu erat 
kaitannya dengan laju fotosintesis disamping cahaya dan kandungan nutrien di perairan (Dawes 1981). Suhu air yang rendah dan tingginya salinitas yang terjadi di laut di akibatkan oleh perubahan cuaca yang terjadi ketika penelitian, dan mengakibatkan rendahnya tingkat percabangan rumput laut di laut. Perubahan cuaca akan mengakibatkan suhu perairan rendah karena perubahan iklim yang terjadi pada perairan.

\subsection{Hubungan parameter lingkungan perairan di tambak dengan performa dan kualitas rumput laut $G$. gigas}

Tingkat keeratan antara indeks percabangan dengan variabel kualitas air di tambak digambarkan pada Gambar 9. Variabel-variabel yang memiliki korelasi positif dengan indeks percabangan yaitu, kecerahan, $\mathrm{PO}_{4}-\mathrm{P}, \mathrm{pH}$, salinitas dan DO. Berdasarkan nilai koefisien korelasinya, variabel yang memiliki hubungan korelasi dengan indeks percabangan pada rumput laut yaitu kecerahan $(0,34), \mathrm{PO}_{4}-\mathrm{P}(0,66)$ dan $\mathrm{DO}(0,62)$.

Variabel-variabel yang berkorelasi negatif dengan indeks percabangan pada rumput laut yaitu $\mathrm{NO}_{3}, \mathrm{NH}_{3}-\mathrm{N}$, dan suhu (Gambar 9). Diantara variabel-variabel tersebut terdapat dua variabel yang memiliki nilai korelasi yang tinggi yaitu $\mathrm{NH}_{3}-\mathrm{N}$ $(0,95)$ dan NO3 $(0,85)$.

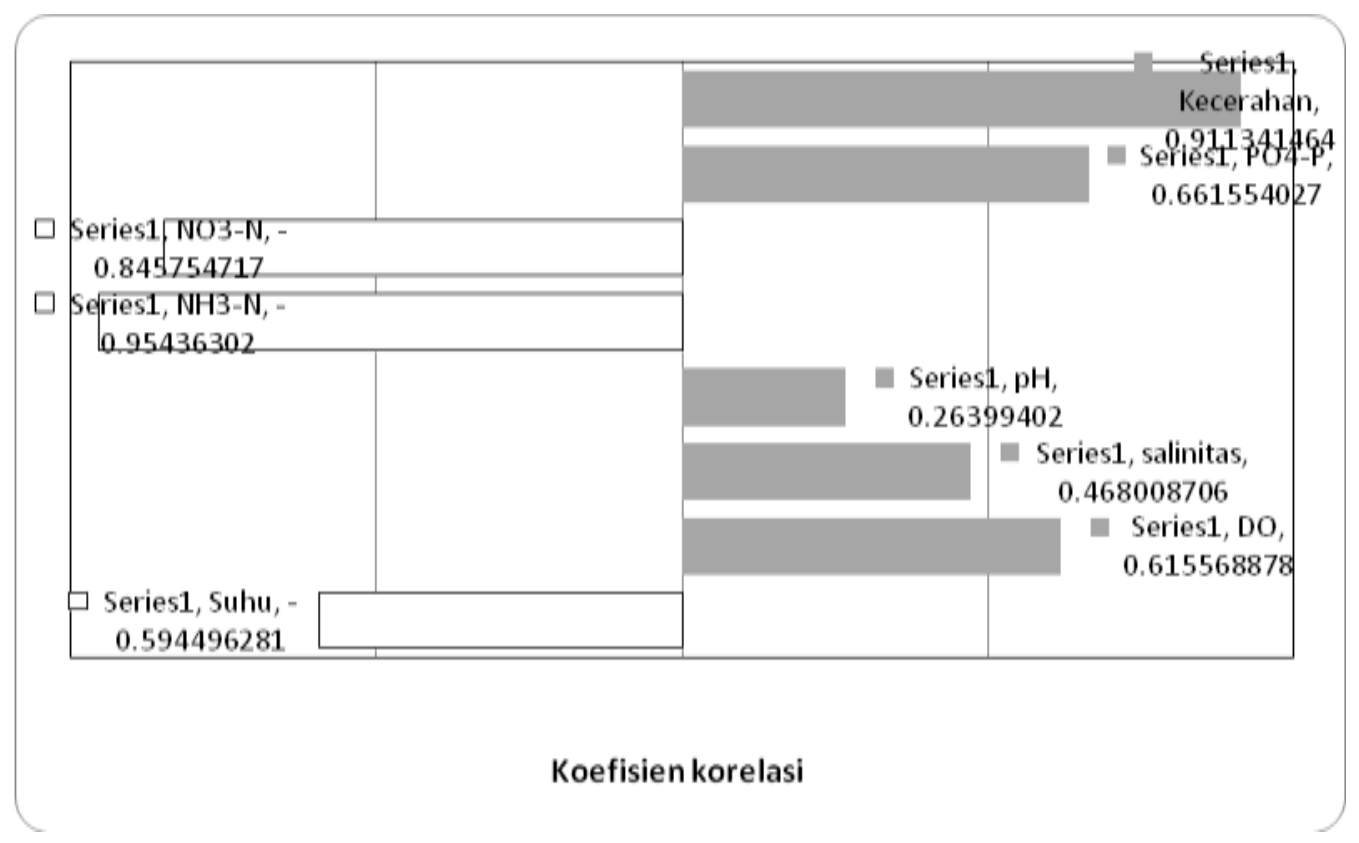

Gambar 3. Koefisien korelasi antara indeks percabangan rumput laut G. gigas dengan parameter kualitas air di tambak

Dari hasil korelasi antara indek percabangan dan parameter kualitas air di tambak menunjukkan kecerahan berhubungan positif dengan indeks percabangan. Hal ini sangat berhubungan dengan pertumbuhan talus rumput laut, sebab rendahnya kecerahan mengakibatkan cahaya yang masuk kedalam perairan berkurang. Intensitas cahaya matahari yang diterima secara sempurna oleh thallus merupakan faktor utama dalam proses fotosintesis. Dalam fotosintesis rumput laut sangat membutuhkan cahaya dan 
apabila aktifitas fotosintesisnya terganggu akan mengakibatkan pertumbuhan yang tidak optimal. Sebagai contoh adanya cahaya matahari yang berlebihan mengakibatkan tanaman menjadi putih, karena hilangnya protein yang dibutuhkan untuk hidup. Cahaya yang berlebihan akan merusak aktifitas enzim yang bekerja untuk menghasilkan protein untuk membentuk polisakarida yang akan disalurkan untuk agar. Menurut Widyorini (2010), cahaya matahari adalah sumber energi dalam proses fotosintesis. Pada proses fotosintesis terjadi pembentukan bahan organik yang diperlukan bagi pertumbuhan dan perkembangan. Cahaya menyediakan energi bagi terlaksananya fotosintesis, sehingga kemampuan penetrasi cahaya pada kedalaman tertentu sangat menentukan distribusi vertikal organisme perairan. Hal yang berhubungan erat dengan penetrasi cahaya adalah kecerahan perairan.

Fosfat diperlukan rumput laut untuk pertumbuhan thalus yang akan membentuk sel-sel baru untuk pertumbuhan pada rumput laut. Fosfat dalam perairan berperan untuk pertumbuhan dan perkembangan rumput laut, semakin tingginya fosfat maka percabangan yang terbentuk akan semakin tinggi, di tambak fosfat sangat tinggi. Fosfat dapat menjadi faktor pembatas baik secara temporal maupun spasial karena fosfat yang lebih sedikit di perairan menurut Chakraborty (2012). Kisaran fosfat optimal untuk pertumbuhan rumput laut adalah 0,051-1,00 ppm (Indriani dan Sumiarsih 1997).

Dari hasil korelasi nitrat berhubungan negatif dengan indek percabangan, karena nitrat merupakan salah satu unsur yang dibutuhkan untuk pertumbuhan rumput laut, semakin tingginya nitrat maka semakin rendah pertumbuhan terhadap rumput laut. Menurut Sukomulyo (1989); kandungan nitrogen yang tinggi di suatu perairan dapat disebabkan oleh limbah yang berasal dari kosmetik, pertanian, peternakan dan indistri. Apabila nitratnya rendah maka akan cukup baik dimana dapat mendukung aktifitas biologis organisme perairan dan pertumbuhan rumput laut.

Amoniak yang tinggi dalam perairan akan menyebabkan racun bagi pertumbuhan rumput laut dan akan menghambat pembentukan sel baru. Sumber amoniak dalam perairan berasal dari pemecahan nitrogen organik (protein dan urea) dan nitrogen anorganik yang terdapat dalam tanah dan air, berasal dari dekomposisi organik.

Derajat keasaman atau $\mathrm{pH}$ merupakan kondisi kimia air yang berperan dalam pertumbuhan dan perkembangan rumput laut. Menurut Trono (1983), bahwa pengaruh $\mathrm{pH}$ bagi organisme sangat besar dan penting. Rendahnya $\mathrm{pH}$ akan menekan laju pertumbuhan bahkan tingkat keasaman dapat mematikan asam tidak ada laju reproduksi. Sebaliknya $\mathrm{pH}$ yang tinggi akan mempercepat reproduksi dan fisiologis si rumput laut tersebut. Kondisi $\mathrm{pH}$ pada saat penelitian relatif stabil dan berada pada kisaran normal yang mendukung kehidupan dan pertumbuhan rumput laut memperbanyak pertumbuhan.

Salinitas merupakan salah satu faktor yang mempengaruhi pertumbuhan rumput laut. Rumput laut jenis G. gigas masih dapat hidup dengan baik walaupun kondisi perairan keruh, rumput laut ini masih mampu menyerap pigmen dan beradaptasi dengan baik (You \& Gerung 2007). 
Oksigen dihasilkan dari rumput laut dan menjadi kelanjutan kehidupan biota perairan karena dibutuhkan oleh hewan dan bakteri untuk respirasi. Fitoplankton juga membantu menambah jumlah kadar oksigen terlarut pada lapisan permukaan diwaktu siang hari sebagai hasil dari fotosintesis. Tingginya DO di tambak dapat menghambat terjadinya proses fotosintesis, hal ini diduga oleh Nussinovitch (1997) yang menyatakan bahwa sumber oksigen terlarut dapat berasal dari difusi oksigen yang terdapat di atmosfer (35\%) dan aktifitas fotosintesis oleh tumbuhan air dan fitoplankton.

Menurut Zatnika (1997) kondisi oksigen terlarut yang optimal dibutuhkan oleh G. gigas berkisar antara 3-8 mg/l.

Suhu mempunyai peranan yang sangat penting bagi kehidupan dan pertumbuhan rumput laut. Chakraborty \& Santra (2008) menyatakan bahwa rumput laut tumbuh dan berkembang dengan baik pada perairan yang memiliki kisaran suhu 26-33 ${ }^{\circ} \mathrm{C}$. Hubungan suhu dengan indeks percabangan adalah, pada saat suhu perairan tinggi maka percabangan akan semakin rendah. Hal ini pada budidaya di tambak suhu yang ada selama penelitian berkisar antara $25-28{ }^{\circ} \mathrm{C}$. Pengaruh suhu terhadap fisiologis organisme perairan merupakan salah satu faktor yang mempengaruhi fotosintesis disamping cahaya dan konsentrasi fosfat (Cochrane 2009). Perbedaan suhu akan naik dengan meningkatkan kecepatan fotosintesis sampai pada radiasi tertentu. Kecepatan fotosintesis akan konstan pada produksi maksimal, tidak tergantung pada energi matahari lagi sampai pada reaksi enzim (Pace 2005).

Pertumbuhan rumput laut dipengaruhi oleh kualitas perairan baik di laut maupun di tambak. Pada penelitian ini kualitas agar sangat terkait dengan indeks percabangan, ini terbukti dari banyaknya thalus di tambak akan meningkatkan kualitas agar di tambak. Hal ini menunjukkan bahwa agar sangat erat kaitannya dengan indeks percabangan, semakin tinggi indeks percabangan, semakin tinggi agar yang dihasilkan. Sedangkan parameter lingkungan yang sangat erat kaitannya dengan performa rumput laut adalah suhu, DO, $\mathrm{PO}_{4}-\mathrm{P}$ dan $\mathrm{NH}_{3}-\mathrm{N}$, sedangkan yang jauh kaitannya adalah $\mathrm{NO}_{3}-\mathrm{N}$. Indeks percabangan merupakan bagian terpenting pada thalus, semakin tinggi thalus yang dihasilkan maka semakin tinggi agar yang didapatkan. Tingginya performa di tambak disebabkan oleh perbedaan karakteristik perairan, salinitas, substrab, kekeruhan, unsur hara dan nutrient pada tambak dan laut (Gambar 5). Kualitas rumput laut tidak lepas dari kondisi perairan yang didukung oleh indeks percabangan pada budidaya di tambak lebih tinggi, sehingga kualitas yang dihasilkan di tambak lebih unggul dari pada di laut.

Paparan dari intensitas cahaya yang diterima oleh rumput laut selama penelitian sangat optimal karena pada periode tersebut kondisi cuaca selalu cerah dan tidak ada hujan. Menurut Kadi dan Atmadja (1998), intensitas sinar matahari merupakan faktor pembatas dalam proses fotosintesis. Makin besar intensitas cahaya matahari, maka proses fotosintesis dapat berjalan semakin cepat pula dan pada akhirnya akan meningkatkan biomassa rumput laut. Selain intensitas cahaya, arus dan gelombang juga berperan pada pertumbuhan rumput laut, karena arus dan gelombang berpengaruh terhadap ketersediaan nutrien di perairan. Menurut Mubarak et al. (1990), kisaran suhu 
perairan yang optimal untuk budidaya rumput laut adalah $25-30{ }^{\circ} \mathrm{C}$. Menurut Raikar et al. (2001) Pada beberapa spesies Grailaria spp. dari perairan tropis dan sub tropis menunjukkan peningkatan laju pertumbuhan dengan semakin meningkatnya intensitas cahaya.

Suhu perairan selama pelaksanaan penelitian juga sangat mendukung, dimana suhu air berkisar antara $25,1-26,2{ }^{\circ} \mathrm{C}$ yang masih termasuk dalam kriteria optimum untuk budidaya rumput laut. Fluktuasi suhu yang sangat kecil tersebut mengindikasikan kondisi suhu perairan yang cukup stabil. Hasil penelitian Raikar et al. (2001) menunjukkan bahwa laju pertumbuhan harian maksimum pada beberapa spesies Gracilaria spp. yang berasal dari Malaysia dan India dicapai pada suhu $25-30{ }^{\circ} \mathrm{C}$, dan pada spesies asal Jepang dicapai pada suhu $20-25^{\circ} \mathrm{C}$ (Mubarak et al. 1990) kisaran suhu perairan yang optimal untuk budidaya rumput laut adalah $25-30{ }^{\circ} \mathrm{C}$. G. gigas ditemukan melimpah di perairan laut dengan fluktuasi suhu berkisar antara $20-27{ }^{\circ} \mathrm{C}$ (Raikar et al. 2010). Fluktuasi suhu perairan Teluk Gerupuk yang relatif rendah tersebut mengindikasikan kondisi perairan yang cukup stabil dan optimal.

Kisaran salinitas yang diperoleh pada lokasi penelitian yaitu 34,07-35,14 ppt. Kisaran tersebut masih termasuk dalam kisaran yang sesuai untuk budidaya rumput laut. Berdasarkan SNI 7579.2:2010 yaitu 28-34 ppt, atau 32-34 ppt yang merupakan katergori sangat sesuai untuk budidaya rumput laut menurut Mubarak et al. (1990). Perairan Teluk Gerupuk tidak terlalu banyak mendapatkan masukan air tawar, karena tidak banyaknya sungai yang bermuara ke perairan tersebut. Selain itu beberapa sungai yang terdapat di sekitar lokasi tersebut mengalami kekeringan selama penelitian berlangsung, sehingga salinitas air di Teluk Gerupuk relatif stabil.

Pada budidaya di tambak kegiatan budidaya dilakukan sepanjang tahun dengan metode tanam yang berbeda juga. Budidaya rumput laut di laut dengan menggunakan metode long-line sedangkan, di tambak dengan metode tebar (broadcast) yang menyebabkan rumput laut tidak bebas mengambil oksigen dalam kondisi dasar perairan. Pada tambak aktifitas budidaya yang sangat terbatas dan harus melakukan perlakuan khusus seperti pemupukan dan lain sebagainya, budidaya di tambak dengan polikultur antara rumput laut dan bandeng akan meningkatkan kandungan nutrisi dan unsur hara yang tinggi, tetapi oksigen yang tersedia rendah. Rumput laut mengeluarkan oksigen dalam bentuk banyak dan mnyerap karbon dioksida yang tinggi. Untuk tumbuh dan berkembang, Gracilaria membutuhkan cahaya, karbondioksida, oksigen dan nutrisi. Cahaya dibutuhkan untuk proses fotosintesis, yaitu karbondioksida akan diubah menjadi karbo-hidrat (senyawa organik). Sebaliknya, oksigen dibutuhkan untuk respirasi atau merombak senyawa yang mempunyai molekul besar menjadi senyawa-senyawa dengan molekul yang lebih kecil dan energi.

Hasil pengukuran kualitas air pada media tambak menunjukkan salinitas $25 \mathrm{ppt}$, suhu $28{ }^{\circ} \mathrm{C}$, pH 7,3, DO 6,9, $\mathrm{NH}_{3}-\mathrm{N}$ 0,358, $\mathrm{NO}_{2}-\mathrm{N}$ 0,005, $\mathrm{NO}_{3}-\mathrm{N}$ 0,7, $\mathrm{PO}_{4}-\mathrm{P} 0,42$ dan kecerahan $40 \mathrm{~cm}$. Kondisi ini merupakan kondisi optimal untuk tumbuh dan berkembangnya Gracilaria (Trono et al. 1983, Effendi 2003) menyatakan kisaran suhu optimal untuk pertumbuhan Gracilaria antara 15-30 ppt. Suhu dibawah $10^{\circ} \mathrm{C}$ 
pertumbuhan Gracilaria lambat, dan suhu diatas $35^{\circ} \mathrm{C}$ Garcilaria tidak tumbuh dan berkembang. Chen Jia Xin 1989 melaporkan bahwa pada suhu $30{ }^{\circ} \mathrm{C}$, pertumbuhan harian G. verrucosa di Guangdong dan Hainan adalah 0,1-0,2 cm/hari, tetapi apabila suhu air lebih rendah menjadi $28^{\circ} \mathrm{C}$, pertumbuhan harian naik menjadi $0,4-0,5 \mathrm{~cm} / \mathrm{hari}$. Tetapi apabila kisaran suhu antara $15-25{ }^{\circ} \mathrm{C}$, pertumbuhan Gracilaria bisa lebih tinggi menjadi $1 \mathrm{~cm} /$ hari. Gracilaria membutuhkan intensitas cahaya matahari tinggi untuk dapat berfotosintesa secara optimal. Gracilaria membutuhkan intensitas cahaya matahari yang tinggi untuk dapat berfotosintesa secara optimal. Kisaran nilai kecerahan perairan yang antara 0,5-1,5 m, memberikan pertambahan panjang antara 5-5,5 cm selama 10 hari pemeliharaan pada suhu air $17^{\circ} \mathrm{C}$ di China (Chen Jia Xin 1989).

\section{Kesimpulan dan Saran \\ 4.1. Kesimpulan}

Rata-rata produktifitas Gracilaria. gigas yang di budidaya dilaut yaitu 12,72\%, sedangkan di tambak dengan rata-rata 4,00 \%. Jumlah thalus pada Gracilaria gigas yang dibudidaya di tambak tinggi $(86,56)$ dibandingkan dengan di laut $(80,40)$, demikian jumlah thalus tersier $(54,07)$ dan indeks percabangan $(18,38)$. Berdasarkan hasil korelasi parameter kualitas air dan indek percabangan, ternyata kualitas rumput laut yang dibudidaya di laut dipengaruhi oleh kecerahan, $\mathrm{NO}_{3}-\mathrm{N}, \mathrm{NH}_{3}-\mathrm{N}$ dan DO. Sedangkan pada budidaya di tambak dipengaruhi oleh kecerahan, $\mathrm{PO}_{4}-\mathrm{P}, \mathrm{pH}$, salinitas dan DO.

\subsection{Saran}

Pengembangan kawasan budidaya Gracilaria gigas dapat dilakukan di tambak untuk meningkatkan produksi, kualitas rumput laut, dan kualitas agar oleh masyarakat atau petani rumput laut.

\section{Daftar Pustaka}

Anggadiredja JT. 1993. Nilai Protein dan Asam Amino Beberapa Jenis Makro-Algae Laut. Jakarta: BPP Teknologi/ Kantor Negara Riset dan Teknologi, Direktorat Pengkajian Ilmu Kehidupan.

Armisén R, Galatas F. 2000. Agar. Di dalam Phillips GO, Williams PA (eds). Handbook of Hydrocolloids. England: Woodhead Publishing Limited.

Badan Standarisasi Nasional. 1998. Standar Nasional Indonesia 01-2690-1998: Rumput Laut Kering. Jakarta : Dewan Standarisasi Nasional.

Chen Jia Xin, 1988. Gracilaria Culture In China. Network of Aquaculture Centres In Asian National Inland Fisheries Institute Kasetsart University Campus Bangkhen, Bangkok, Thailand.

Cochrane K, De Young C, Soto D, BahriT(eds.). 2009. Climate Change Implications For Fisheries And Aquaculture: Overview Of Current Scientific Knowledge. FAO Fisheries and Aquaculture Technical Paper No. 530. Food and Agriculture Organization of The United Nations. Rome. 212p.

Dawes, CJ. 1981. Marine Botany. John Wiley and Sons, Inc. Canada. 628p.

Durairatnam M, de Brito Medeiros TM, de sena AM. 1990. Studies on The Yiel And Gel Stength Of Agar From Gracilaria Domingensis Sonder Ex Kuetzing 
(Gracilariales, Rhodophyta) following the addition of calcium. Proc. Int. Seaweed Symp. 13: 551-553.

FAO Food and Agriculture Organization of the United Station. 1987. The Wild Harvest and Culture of the Economically Important Species of Gelidium in Clile. www. Fao.org. [4 November 2008].

Kadi A dan Atmadja, W.S. 1988. Rumput Laut (Algae): Jenis, Reproduksi, produksi, Budidaya dan Pasca panen. Puslitbang Oseanografi. LIPI. 71 p Jakarta.

McHugh DJ. 2003. A guide to seaweed industry. FAO Fisheries Technical Paper No. 441. FAO. Rome. 105p.

Murti AW. 2007. A Guide To The Seaweed Industry. www. Fao.org/seaweed. [3 Mei 2013).

Pickering TD, Gordon ME, Tong LJ. 1995. A preliminary trial of a spray culture technique for growing the agarophyte Gracilaria chilensis (Gracilariales, Rhodophyta). Aquaculture 13. pp 43-49.

Terada R, Ohno M. 2000. Notes on Gracilaria (Gracilariales, Rhodophyta) from Tosa Bay and adjacent waters I: Gracilaria chorda, Gracilaria gigas and Gracilaria incurvata.Bull. Mar. Sci. Fish., Kochi Univ. No. 20, pp 81-88.

Towle AG. 1973. Carrageenan. Di dalam Industri Gums. Whistler RL (ed). New York: Academic Press.

Zatnika A, 1997. Profil Industri Rumput Laut Indonesia. Tim Rumput Laut BPPT. BPPT, Jakarta. 